an emerging need in the poorer countries with technical assistance in this field - a development that could breathe new life into the dead-letter promises by the nuclear powers in 1970. The framework of the NPT could be kept alive.

How should it be strengthened? There is some relatively modest tightening of the NPT that needs to be accomplished. Despite the existing agreement between the nuclear suppliers that they will not assist others to make nuclear weapons, the case of Iraq shows that the agreement leaks. (Finding out which companies and people helped with the developments of the past few years is rightly part of IAEA's objective; their identities should be made public.) There is a strong case for greater formality, and for some kind of public register of supplies of nuclear equipment along the lines that the prime minister of Japan has been advocating for arms sales in general. The case for sanctions against illicit suppliers and their customers deserves a hearing.

The more desirable end-point is more drastic: a general understanding within the United Nations that the novel development of nuclear weapons is an offence against the international community, and must be stopped (as will, eventually, be the development in Iraq). That would require a decision by the UN Security Council that nonsignatories of the amended NPT must involuntarily submit their nuclear installations to international safeguards. If the Security Council decided as recently as a year ago that the invasion of Kuwait must be undone, why should not it take this further step in this direction?

There are snags. For one thing, it would be unseemly that the established nuclear powers should ask for such a regime without making like sacrifices themselves, but general inspection of all nuclear facilities is not now an insupportable prospect. Indeed, might not this be the time to revive the old idea of a cut-off of military production (France's long-standing condition for signing the NPT, itself now softened)? Obdurately silent China is one stumbling-block. So, too, is Israel, which would be automatically denied US assistance of any kind if it were shown to be a nuclear power, but which will dig in its heels unless this year's peace conference on the Middle East yields sweeter fruit than is now in prospect. The present danger is that these obstacles, seeming insurmountable, will paralyze thought about a stronger NPT. Rather, they should be a spur to its reform.

\section{Straight-line city}

The case for a linear city to the east of London is stronger than the short-term arguments suggest.

Mr Michael Heseltine, who might well now have been the British Prime Minister had not Mrs Margaret Thatcher withdrawn from the second round of polling to elect the leader of the Conservative Party, has - in his lesser role as Secretary of State for the Environment - a splendid idea: he wants to create a linear city stretching eastwards from the City of London along the Thames for perhaps 50 miles to the coast of the North Sea. There appear to be two short-term incentives - to breathe new life into development projects mounted in the past few years immediately to the east of London and now languishing in the worldwide property boom, and to divert development in Britain away from southeast England (full of articulate and influential protesters at machines shaped like bulldozers) towards the ugly and largely unloved north bank of the estuarine Thames. But the notion should not be crabbed on that account. The advantages of linear cities are unrecognized, let alone realized.

The reasons why traditional inner cities have become slums are well-recorded. People who live in cities seek occasionally to escape from them; the better off they are, the more readily they move to suburbs. But in a linear city, downtowners can escape laterally if they wish. (Heseltine's city would offer escape towards either a marine environment or dry land.) That is the crucial consideration. The price that must be paid is that of effective high-speed transport along the backbone of the city. City-dwellers could not call themselves that if it were to take more than, say, an hour to get from any one place to any other, which argues for a backbone of several high-speed railway tracks. Indeed, if Heseltine were to persuade his government to install the tracks, he would find his linear city springing into being without further fuss.

\section{Telephone silence}

Academics in the United States, where the telephone was invented, are over-secretive about their telephone numbers.

THE telephone is a remarkable invention which has helped to change the world. As now developed, it enables people to speak to others at the far ends of the Earth, usually when they need to do so. That is why a person's telephone number is often more valuable than his or her street address. And that is why the failure of many scientists to include their telephone (and fax) numbers on their letterheads is a constant source of frustration and perplexity, especially to a journal such as Nature.

The worst offenders are researchers at institutions in the United States, particularly at the various campuses of the University of California. Why this reticence? Is it that, with the virtual disappearance of the personal assistant, researchers are shy of receiving telephone calls unannounced? (The personalized answering machine is the defence against that.) Or shy of revealing exactly where they are at any time? (One Californian researcher who claims to divide his time between three telephone numbers has answering machines that refer callers to the alternative numbers, often fruitlessly.) Whatever the explanation, it is indeed strange that one of the most technologically advanced societies in the world should not yet have come to terms with the invention of the telephone. And is it not doubly ironic that the telephone should have been invented in the United States? 